\title{
Working
}

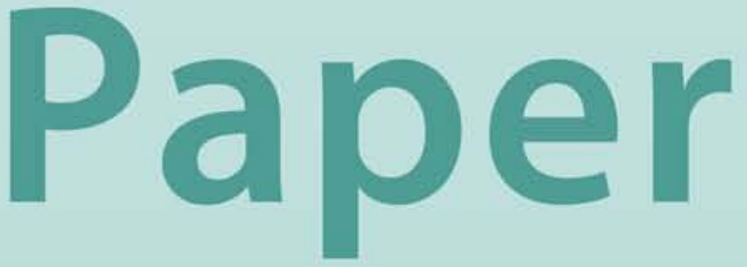




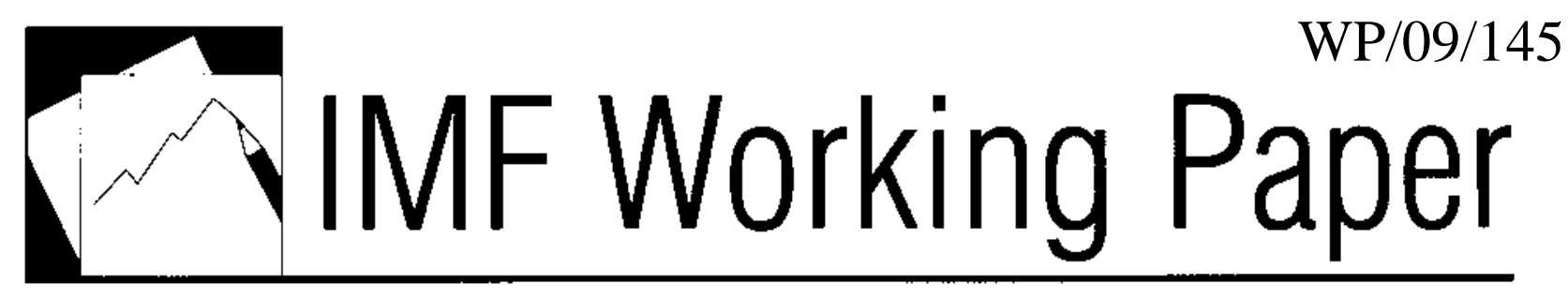

\section{Anatomy of Regional Disparities in the Slovak Republic}

Biswajit Banerjee and Mariusz Jarmuzek 


\title{
IMF Working Paper
}

\author{
European Department
}

\section{Anatomy of Regional Disparities in the Slovak Republic}

\author{
Prepared by Biswajit Banerjee ${ }^{1}$ and Mariusz Jarmuzek
}

Authorized for distribution by Ashoka Mody

July 2009

\begin{abstract}
This Working Paper should not be reported as representing the views of the IMF. The views expressed in this Working Paper are those of the author(s) and do not necessarily represent those of the IMF or IMF policy. Working Papers describe research in progress by the author(s) and are published to elicit comments and to further debate.

This paper examines economic growth and various dimensions of regional disparities in Slovakia. We find that regional disparities in the levels of GDP per capita, labor productivity, and labor utilization have widened since 2000, coinciding with the time that Slovakia initiated negotiations on EU accession. Notwithstanding $\sigma$-divergence in the levels, there was conditional $\beta$-convergence in the growth rates of GDP per capita and labor productivity. Improvements in total factor productivity were the main engine of growth of GDP in all regions. Sustaining growth and reducing disparities will require increasing the labor utilization ratio and improving the structural and policy determinants of productivity in the eastern regions. The main policy priorities are to improve transportation infrastructure, enhance cost competitiveness through greater regional differentiation in wages and further decentralization of collective bargaining, and increase accumulation of human capital.

JEL Classification Numbers: O18, O47, O52

Keywords: Regional disparities; $\beta$-convergence; $\sigma$-convergence; growth accounting Author’s E-Mail Address: bbanerje@haverford.edu; mjarmuzek@imf.org

\footnotetext{
${ }^{1}$ Haverford College. The author was previously an Advisor in the European Department. Both authors would like to thank Mark De Broeck for comments on an earlier version of the paper. We would also like to thank Abdul Abiad, Engin Dalgic, Alex Hoffmaister, Michal Horvath, Marek Jakoby, and Tetsuya Konuki for helpful discussions and suggestions. Special thanks go to Gabriela Haasova from the Slovak Statistical Office for providing regional data and Judith Rey for editorial assistance.
} 


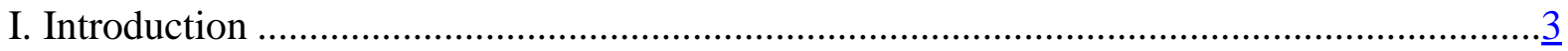

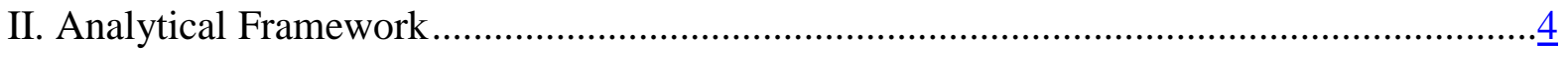

III. Dimensions of Regional Disparities in Slovakia ....................................................

IV. Regional Income Disparity in Slovakia in the EU Context ............................................

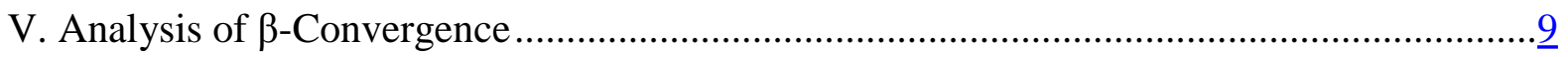

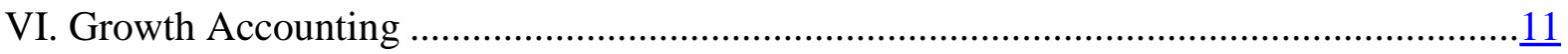

VII. Sectoral Patterns of Productivity Growth..............................................................12

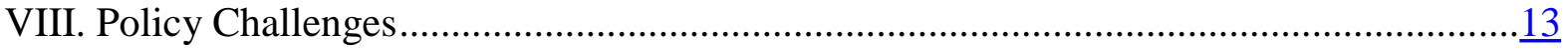

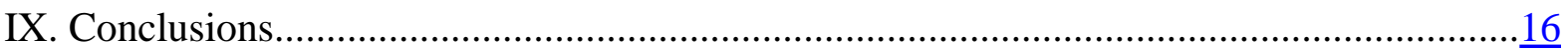

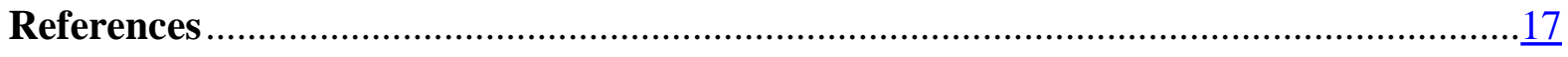

Tables

1. Regional Differences in Real GDP per Capita and Household Disposable Income, 1995-2006.....................................................

2. Regional Differences in Labor Productivity, 1995-2006 .........................................19

3. Regional Differences in Labor Utilization and Unemployment, 1995-2006 ................20

4. Dispersion of Regional GDP per Capita in the European Union, 1996-2005...............21

5. Regression Analysis of $\beta$ (Beta)-Convergence of GDP per Capita Growth...................22

6. Regression Analysis of $\beta$ (Beta)-Convergence of Labor Productivity Growth ................23

7. Sources of Growth of GDP and Labor Productivity by Regions, 1996-2006...............24

8. Motorways and Junctions Density by Regions .................................................... 25

9. Foreign Direct Investment in the Corporate Sector by Regions, 1999-2006 .................26

10. Sectoral Patterns of Labor Productivity Growth by Region .......................................27

11. Unit Labor Costs and Minimum Wage by Regions, 1998-2006 .................................28 


\section{INTRODUCTION}

Slovakia has been one of Central Europe's strongest economic performers for several years during its journey to European Union (EU) membership and euro adoption. Sound macroeconomic management, a wide range of structural reforms, and increasing integration with the EU led to progressive strengthening of economic growth. However, there is widespread perception that the growth has been unevenly balanced across regions and that inequalities in regional and household income have widened. According to this view, the benefits of robust economic growth have been reaped mainly by the western regions and most of the eastern regions have been left behind. With this understanding, the coalition government that assumed office in mid-2006 has, among other policies, placed emphasis on higher social spending in order to make the benefits of growth more socially inclusive.

Bruncko (2003) found that while substantial regional disparities exist in Slovakia in terms of output per capita, these disparities had not widened during 1996-99. In his view, an initial widening of regional differences in GDP per capita could be expected during income convergence with the EU, in line with the experience of many other countries that had joined the EU earlier. Slovakia was particularly prone to such an outcome because of geographical factors that created a localized growth pole around the Bratislava region. On the other hand, the literature on economic growth suggests that regions with lower income levels should generally experience faster growth rates than regions with higher income levels. However, disparities in the level of income could widen even when there was convergence in the growth rate of income, if steady state growth rates were heterogeneous across regions and regions were converging to region-specific steady states.

In this paper, we examine economic growth and various dimensions of regional disparities in Slovakia during 1995-2006. We shed light on the pattern of convergence across regions and on whether income disparities had widened during the period since Slovakia started EU membership negotiations in 2000. Slovakia joined the EU in May 2004, entered the Exchange Rate Mechanism II in November 2005, and eventually adopted the euro in January 2009. We also look at the sources of growth at the regional and sectoral levels and, on this basis, determine the implications for economic policy. Ensuring socially inclusive growth through transfer payments is not a sustainable solution to income inequalities. Policies need to focus on aspects that constrain particular regions from becoming equal beneficiaries of Slovakia's economic integration with the EU and the convergence process.

The paper is organized as follows. Section II lays out the theoretical and empirical framework for the analysis of convergence. Section III examines the various dimensions of regional disparities in Slovakia and their evolution over time. Section IV places regional disparities in Slovakia in the EU context. Section V presents the results of the econometric analysis of convergence. Section VI applies the standard growth accounting framework to identify the main determinants of growth of total output and productivity. Section VII looks 
at the sectoral patterns of productivity growth. Section VIII discusses the policy challenges to reducing regional disparities. Section IX concludes.

\section{ANALYTICAL FrameWORK}

The traditional starting point for the study of growth and real convergence is the Solow model (Solow, 1956). The model assumes a neoclassical production function characterized by constant returns to scale and diminishing returns to inputs, a constant marginal propensity to save, and investment equal to saving. If the production function takes the classic CobbDouglas form $Y_{t}=A_{t} K_{t}^{\alpha} L_{t}^{1-\alpha}$, and it is assumed that labor $L$ grows at a rate $n$ and total factor productivity (TFP) or technological progress $A$ increases at a rate $g$, then the steady-state output per worker can be expressed as:

$$
\ln y=\ln A+\frac{\alpha}{1-\alpha}[\ln s-\ln (n+g+\delta)]
$$

where $y=\mathrm{Y} / \mathrm{L}, \alpha$ and $(1-\alpha)$ are the elasticity of output with respect to capital and labor, $s$ is the investment rate, and $\delta$ represents depreciation of capital.

Mankiw, Romer and Weil (1992) extended the Solow model to incorporate the influence of human capital on output. If we introduce the stock of human capital $H$ in a production function of the form $Y_{t}=A_{t} K_{t}^{\alpha} H_{t}{ }^{\beta} L_{t}^{1-\alpha-\beta}$, the steady-state output per worker can be expressed as:

$$
\ln y=\ln A+\frac{\alpha}{1-\alpha-\beta}\left[\ln s^{K}-\ln (n+g+\delta)\right]+\frac{\beta}{1-\alpha-\beta}\left[\ln s^{H}-\ln (n+g+\delta)\right]
$$

where $s^{K}$ and $s^{H}$ represent the shares of output invested in physical and human capital, and $\beta$ and $(1-\alpha-\beta)$ are the output elasticities for human capital and labor, respectively.

However, as economies may not always be at their steady-state level of income, one needs to determine the transition dynamics to the steady state. The speed of transition to the steady state is commonly examined in the literature through the concept of $\beta$ (beta)-convergence. The assumption of diminishing returns in the Solow model implies that the marginal productivity of capital will be higher in poorer economies with lower levels of physical capital. Hence, it follows that poorer economies will grow at a faster rate than richer economies, leading to convergence of income over time.

If we assume that the steady state growth rate is same for all economies-i.e., structural parameters in equations (1) and (2) are the same for all economies-unconditional or absolute convergence to the common steady state can be described by the following:

$$
\Delta \ln y=\ln y_{0}+\ln A,
$$


where $\Delta \ln y \cong \frac{\ln y_{T}-\ln y_{0}}{T}$. However, the steady state level of income is likely to vary across economies if their rates of investment, depreciation, population growth, and technological progress are different. Under the assumption that some of the structural parameters in equations (1) and (2) are different for the economies under consideration, conditional convergence takes place. In other words, each economy converges to a steady state that is determined by the parameters specific to that economy. The conditional convergence process in the Solow model can be approximated as follows:

$$
\Delta \ln y \cong g+\frac{1-(1-\lambda)^{T}}{T}\left\{\ln A_{0}+\frac{\alpha}{1-\alpha}[\ln s-\ln (n+g+\delta)]-\ln y_{0}\right\}
$$

where $\lambda \cong(1-\alpha)(n+g+\delta)$. The convergence process in the Mankiw-Romer-Weil model can be approximated as follows:

$$
\Delta \ln y \cong g+\frac{1-(1-\lambda)^{T}}{T}\left\{\begin{array}{c}
\ln A_{0}+\frac{\alpha}{1-\alpha-\beta}\left[\ln s^{K}-\ln (n+g+\delta)\right]+ \\
\frac{\beta}{1-\alpha-\beta}\left[\ln s^{H}-\ln (n+g+\delta)\right]-\ln y_{0}
\end{array}\right\}
$$

where $\lambda \cong(1-\alpha-\beta)(n+g+\delta)$.

The presence of unconditional $\beta$-convergence is typically tested by regressing the growth rate of any variable (e.g. output per capita or productivity) on the initial level of that variable:

$$
\Delta \ln y_{i t}=\gamma_{0}+\gamma_{1} \ln y_{i t-1}+\varepsilon_{i t}
$$

If the growth rate is negatively related to the initial level of the variable-i.e., the sign for $\gamma_{1}$ is negative-there is said to be $\beta$-convergence. Conditional $\beta$-convergence is tested by regressing the growth rate on the initial level of the variable and other structural variables. In its simplest form, conditional $\beta$-convergence is estimated via a two-way fixed-effects (FE) method:

$$
\Delta \ln y_{i t}=\gamma_{i}+\gamma_{1} \ln y_{i t-1}+\gamma_{t}+\varepsilon_{i t}
$$

where $\gamma_{\mathrm{i}}$ represents region-specific effects and $\gamma_{\mathrm{t}}$ captures time effects. The region-specific fixed effect allows for heterogeneity in steady-states across regions. The time-fixed effects capture the impact of changes in the external environment, technology, and policies over time. 
The econometric specification of the Solow model, with two-way fixed effects, is as follows:

$$
\Delta \ln y_{i t}=\gamma_{i}+\gamma_{1} \ln y_{i t-1}+\gamma_{2}\left[\ln s_{i t}+\ln \left(n_{i t}+g+\delta\right)\right]+\gamma_{t}+\varepsilon_{i t} \text {. }
$$

Similarly, the Mankiw-Romer-Weil model can be specified as:

$$
\begin{aligned}
& \Delta \ln y_{i t}=\gamma_{i}+\gamma_{1} \ln y_{i t-1}+\gamma_{2}\left[\ln s_{i t}^{K}+\ln \left(n_{i t}+g+\delta\right)\right] \\
& +\gamma_{3}\left[\ln s_{i t}^{H}+\ln \left(n_{i t}+g+\delta\right)\right]+\gamma_{t}+\varepsilon_{i t},
\end{aligned}
$$

where $s_{i t}^{K}$ and $s_{i t}^{H}$ represent the shares of output invested in physical and human capital in region $i$ at time $t$, respectively. In the specifications of both the Solow model and the Mankiw-Romer-Weil model, it is assumed that $A_{0}$ (the initial level of technology) is heterogeneous across regions, and that $g$ (growth of technology) is homogenous across regions. It is further assumed, following the literature (e.g. Bernanke and Gurkaynak, 2001 and Bosworth and Collins, 2003), that $g+\delta=0.05$.

A supplementary method of investigating convergence is through an examination of the dynamics of dispersion of income level across economies. $\sigma$ (sigma)-convergence is said to occur if this dispersion declines over time. $\beta$-convergence is a necessary but not sufficient condition of $\sigma$-convergence. If economies are converging to different economy-specific steady states, it is possible for $\beta$-convergence to take place together with $\sigma$-divergence (Islam, 2003).

\section{Dimensions of REgional Disparities in SLOVAKIA}

Regional disparities are both large and persistent in Slovakia. On the basis of per capita GDP, regions in Slovakia can be divided into two broad groups: richer western regions comprising Bratislava, Trnava, Trencin, and Nitra and poorer eastern regions comprising Zilina, Banska Bystrica, Presov, and Kosice. Bratislava is the richest region with per capita GDP in 2006 about 234 percent of the national average, and Presov is the poorest with per capita GDP about 55 percent of the national average. If Bratislava and Presov are excluded, the regional variation decreases significantly. Per capita GDP in the other regions range between 84 and 122 percent of the national average. Regional differences in per capita household disposable income are smaller than the differences in per capita GDP. This is because sizeable expenditures on social safety nets have a mitigating effect on inequalities (Table 1).

Evidence indicates $\sigma$-divergence in the level of per capita GDP across regions, especially since 2000. The widening dispersion is indicated by the increase in the coefficient of variation over time. The differentials in per capita GDP between regions were relatively stable during 1995-99, but have widened thereafter. The gap between Bratislava and the rest of Slovakia has become bigger. Also, from the time of EU accession in 2004, the other western regions have moved ahead of the eastern regions. Regional disparities in per capita 
household disposable income have increased as well, and the pattern is similar to that for per capita GDP. ${ }^{2}$

The growth path of per capita GDP in Slovakia during 1996-2006 is U-shaped. As Table 1 shows, growth slowed down progressively and bottomed slightly negative in 1999, but recovered strongly from then on. The U-shaped growth path was common to all regions. The resumption of growth in 2000 coincided with the launching of the negotiations for EU accession. Preparation for EU membership entailed implementation of significant legal, institutional, and structural reforms, which improved the business climate and enhanced the flexibility of the economy. It also spurred increasing trade and financial integration with the EU and sizeable inflows of foreign direct investment (FDI). These factors, together with sound macroeconomic management, contributed to the progressive strengthening of economic growth.

As such, the regional pattern of per capita GDP growth suggests the absence of $\beta$ convergence. Contrary to the prediction of the Solow model, the poorer eastern regions did not generally grow at a faster rate than the richer western regions. The average growth rate in the eastern regions was higher than that for Slovakia as a whole only in three years during 1996-2001, and has lagged the national average from 2002 onward. Most striking, growth in Presov, the poorest region, has lagged the national average for most of the period. The results of more rigorous testing of $\beta$-convergence through an econometric exercise are presented in Section V below.

In order to gain more insight into the differences in growth performance and the large gaps in GDP per capita across regions, we can decompose GDP per capita as follows:

$$
\frac{G D P}{P O P}=\frac{G D P}{E M P} * \frac{E M P}{P O P}
$$

where GDP is gross domestic product, POP is population, and EMP is total employment. The first term on the right-hand side is labor productivity and the second term is labor utilization.

Productivity levels are generally higher in the western regions than in the eastern regions. Bratislava and Trnava stand out in that productivity in these two regions is higher than the national average. Kosice also stands apart from the other eastern regions, with the third highest productivity level in the country (Table 2).

The data indicate $\sigma$-convergence of labor productivity levels during 1995-2001 and $\sigma$ divergence during 2002-06. The coefficient of variation of labor productivity declined in the

\footnotetext{
${ }^{2}$ Regional differences in per capita GDP and household disposable income are likely to be overstated, especially between Bratislava and the other regions, because a large number of workers commute to work from outside the region.
} 
first period, but rose in the second period. The widening dispersion in the second period offset the narrowing recorded in the first period. Thus, for Slovakia as a whole, the dispersion in labor productivity in 2006 had returned to the level prevailing in 1995. If we look at Slovakia excluding Bratislava, the dispersion was larger in 2006 than in 1995.

The relative performances in productivity within the poorer and richer regions varied substantially. In line with the trends in dispersion observed above, two of the poorer regions (Banska Bystrica and Kosice) improved their labor productivity levels relative to the national average during 1995-2001, but these gains were reversed in the subsequent years. However, productivity in the other two poorer regions (Zilina and Presov) relative to the national average remained broadly unchanged over time. In three of the four richer western regions (Bratislava, Trnava, and Trencin), the relative productivity levels declined during 1995-2001/02. Thereafter, the relative position of Bratislava and Trencin was broadly stable, while that of Trnava improved as it experienced gains in productivity well above the national average. In contrast to the other richer regions, productivity growth in Nitra exceeded the national average in most periods during 1995-2006.

Regional disparities in labor utilization in Slovakia have widened over time, especially since 2000. As Table 3 shows, the evolution of labor utilization for Slovakia as a whole is U-shaped: the ratio of employment to total population declined during 1995-2000 but picked up in the subsequent years. Labor utilization fell in both the western and eastern regions in the initial period, but the fall was deeper in the eastern regions. The decrease in labor utilization reflected labor shedding associated with enterprise restructuring process that was not offset by new job creation. Whereas employment and, pari passu, labor utilization picked up in western regions from 2001 onward, such a recovery was absent in the eastern regions where the labor utilization ratio broadly stabilized. The aggregate patterns for the western and eastern regions mask some contrasting trends. Labor utilization steadily increased over time in Bratislava and Trencin in the west, while it declined steadily in Banska Bystrica in the east. In all the other regions, the U-shaped pattern prevailed.

The developments in labor utilization have been manifested in unemployment. Unemployment rates have been typically much lower in the western regions than in the eastern regions and have dropped to the single digits, except for in Nitra. In contrast, unemployment rates in three of the eastern regions (Banska Bystrica, Presov, and Kosice) have remained over 20 percent since 1999.

\section{REgIONAL INCOME DISPARITY IN SLOVAKIA IN THE EU CONTEXT}

We now examine, utilizing Eurostat data, how Slovakia compares with other EU member states with regard to regional disparities in GDP per capita. Eurostat measures disparity by the sum of absolute differences between regional and national GDP per capita, weighted by the share of population and expressed in percent of national GDP. Qualitatively, this measure 
should provide a picture similar to that shown by the coefficient of variation. Thus, changes in the measure over time provide evidence on $\sigma$-convergence or divergence.

As Table 4 shows, in 2005, the dispersion in regional GDP per capita in Slovakia was fourth highest among New Member States - after Latvia, Estonia, and Hungary. With the exception of the Czech Republic, Lithuania, and Slovenia, regional income disparity was higher in the New Member States than in the Old Member States of the EU. The data indicate the occurrence of $\sigma$-divergence in the level of GDP per capita in all the New Member States during the period since they began negotiations on EU accession in 1999/2000. However, Slovakia registered the second highest increase in income dispersion, after Romania. The increase in dispersion in Bulgaria and Lithuania was broadly similar to that in Slovakia. However, if we look at the evolution of income disparity over a longer time period (1996-2005), the increase in income dispersion in Slovakia is among the lowest.

\section{Analysis of $\beta$-CONVERgence}

To test the hypothesis of $\beta$-convergence, we estimated growth-initial level regressions separately for 1996-2006 and 2000-06. $\beta$-convergence is tested for per capita GDP and labor productivity.

In the specification for 1996-2006 where the initial level of per capita GDP is the only explanatory variable (Table 5, column 1), the coefficient on this variable is positive and statistically significant, suggesting the presence of absolute or unconditional divergence. However, too much should not be made of this result as the overall explanatory power of the equation is extremely low and is not statistically significant. When fixed effects for region and time are included in the specification (column 3), the coefficient on the initial level of per capita GDP turns negative and is statistically significant at the 5 percent level. There is also a substantial improvement in the goodness of fit and the value of adjusted R-squared is statistically significant at the 1 percent level. The findings of this specification can be seen as evidence of conditional convergence to steady state growth rates that differ across regions.

Evidence of unconditional divergence of per capita GDP growth is somewhat stronger for the period 2000-06. In the specification without fixed effects (column 2), the coefficient on the initial level of per capita income is positive and statistically significant at the 1 percent level. The F-statistic for the overall fit of the equation is also statistically significant at the 5 percent level, though only a very small part of the overall variation is explained. With the inclusion of fixed effects for region and time, the evidence swings in favor of conditional convergence as in the case of the longer sample period. However, the coefficient on the initial level of per capita income is not statistically significant and the adjusted R-squared is significant only at the 10 percent level. The seemingly weaker evidence of conditional convergence during 2000-06 could be attributed to the operation of divergence factors during the integration process with the EU that was conjectured by Bruncko (2003), or it could be merely because of the small sample period which makes the econometric estimates tenuous. 
The econometric exercise also indicates evidence of conditional $\beta$-convergence of labor productivity. In the specifications with fixed effects (Table 6, columns 3 and 4), the coefficient on the initial level of productivity variable is negative and statistically significant for both the longer and shorter sample periods. F-tests indicate that region- and time-fixed effects are individually and jointly statistically significant at the 1 percent level. There is no support for the presence of unconditional convergence or divergence, with the R-squared values in the simplest specifications without fixed effects being negative for both the longer and shorter sample periods (columns 1 and 2).

The estimates of the Solow model for labor productivity growth with region- and time-fixed effects also reinforce the evidence on conditional $\beta$-convergence during both 1996-2006 and 2000-06. The coefficient on the initial level of labor productivity is more negative during 2000-06, suggesting a faster pace of convergence during this period than in the earlier years. F-tests indicate that region- and time-fixed effects are individually and jointly statistically significant at the 1 percent level. In accordance with expectations, the results show that the faster is the growth in employment the slower is the growth in productivity. However, the coefficient on the investment ratio is not statistically significant, suggesting that investment played little role in productivity growth. ${ }^{3}$ One explanation could be that during the economic restructuring process new investment was accompanied by a lot of disinvestment, thereby muting the overall impact of investment on growth. Indeed, data indicate that the investment ratio declined in all regions during 1996-2000. Thereafter, the investment ratio fell further in two regions-Banska Bystrica and Presov in the east-but stabilized or picked up in the other regions. It is also possible that the lack of a significant relationship is because of the relatively short sample period, as the growth literature emphasizes that investment is a major engine of growth in the medium to long term.

The Mankiw-Romer-Weil model is estimated only for the period 2000-06, as regional data on education is available only from 2000 onward. The initial level of productivity variable and employment growth have negative signs and are statistically significant, as in the Solow model. However, the estimates do not show the expected result on the impact of human capital on productivity growth. The coefficient on the variable measuring the proportion of employed with upper secondary or university education is negative and statistically significant. This counter-intuitive finding may be a reflection of possible bias in the measurement of the education variable. The education variable is measured on the basis of place of residence of the person whereas the productivity variable is measured on the basis of location of work. Thus, the observed negative relationship between productivity growth and human capital may be a reflection of educated persons living in poorer regions commuting to

\footnotetext{
${ }^{3}$ Havrylyshyn and Wolf (2001) obtained an insignificant coefficient for investment in their study on the determinants of growth in transition countries. In the regressions for GDP per capita growth in EU candidate and potential candidate countries based on annual data, Borys, Polgar, and Zlate (2008) also obtained statistically insignificant coefficients on investment.
} 
work in adjacent richer regions in large numbers. A small sample size is also a problem in this specification. In an alternative specification (not reported here), when human capital was measured as the proportion of total population with higher education, the coefficient on that variable was positive but not statistically significant.

\section{Growth Accounting}

A supplementary perspective on the driving forces of growth can be obtained by utilizing the growth accounting framework. The decomposition of growth of total output can be expressed by the following equation:

$$
\frac{\Delta Y}{Y}=\frac{\Delta y}{y}+\frac{\Delta L}{L}
$$

where $\frac{\Delta Y}{Y}$ is growth of total output, $\frac{\Delta y}{y}$ is growth of labor productivity, and $\frac{\Delta L}{L}$ is growth of labor input. In turn, growth of labor productivity can be decomposed as follows:

$$
\frac{\Delta y}{y}=\alpha \frac{\Delta k}{k}+\frac{\Delta A}{A}
$$

where $\frac{\Delta k}{k}$ is growth of capital per worker and $\frac{\Delta A}{A}$ is growth of TFP.

Throughout the period under consideration, GDP growth in all regions was driven primarily by labor productivity growth (Table 7). During 1996-2000, contribution of employment growth was negative in all regions except Bratislava and Trencin, reflecting job losses. Subsequently, during 2001-06, contribution of employment growth was positive, albeit modest, in all regions with the exception of Banska Bystrica. In this latter period, the influence of employment growth on GDP growth was greater in the western regions than in the eastern regions. In the western regions, employment growth accounted for between onetenth and one-fifth of total GDP growth, whereas in the eastern regions the contribution was around one-tenth or less.

The growth of labor productivity was driven by different forces across regions and time. During 1996-2000, capital deepening was relatively more important than TFP improvements in Bratislava and Trencin. In Trnva, Zilina, and Presov the contribution of the two factors were roughly equal, while TFP improvements were dominant in Nitra, Banska Bystrica, and Kosice. From 2001 onward, TFP was the main source of labor productivity growth in all regions, though the contribution of capital deepening remained significant.

The regional differences in productivity growth can be related to advantages in location, infrastructure stock and quality, ability to attract FDI, and human capital endowments. The 
richer western regions are in closer proximity to EU markets and have a much better network of quality roads and motorways (Table 8). The poorer eastern regions border similar poor regions in neighboring countries and suffer from significant transport infrastructure bottlenecks. In addition, the western regions, especially Bratislava, have a higher concentration of educated persons. These factors have influenced the volume of FDI inflows into the various regions. By the end of 2006, Slovakia's per capita FDI was the highest among its neighboring countries. As Table 9 shows, the Bratislava region has received the bulk of FDI inflows into Slovakia, and its share stepped up from around 50 percent of the national total to over 60 percent from 2002. Kosice in the east received considerable inflows in 2000 from the privatization of the steel plant, but subsequent inflows have lagged the national trend. Among the eastern regions, Zilina has attracted an increasing share of FDI in part owing to its partial motorway links with the western regions.

The origins of the TFP efficiency gains in the western regions are likely to have been different from those in the eastern regions. The higher FDI inflows attracted by the western regions not only resulted in capital deepening but also fed into TFP through the introduction of new technologies, know-how, and superior managerial techniques (Smarzynska-Javorcik 2004). In contrast, a high contribution of TFP to growth of labor productivity in the eastern regions is likely to have resulted mainly from the continued restructuring process of the regional economies.

\section{Sectoral Patterns of Productivity Growth}

Further insight into labor productivity growth can be gained by examining whether it was driven by sectoral shifts or by within-sector productivity gains. Following Timmer and Szirmai (2000) and World Bank (2008), aggregate labor productivity growth can be decomposed as follows:

$$
\frac{\Delta y_{t}}{y_{t-1}}=\frac{\sum_{i=1}^{n} \Delta y_{i t} S_{i t-1}}{y_{t-1}}+\frac{\sum_{i=1}^{n} \Delta S_{i t} y_{i t-1}}{y_{t-1}}+\frac{\sum_{i=1}^{n} \Delta S_{i t} \Delta y_{i t}}{y_{t-1}}
$$

where $i$ denotes sector ( $i=1, \ldots n$, with $n$ number of sectors), $t-1$ and $t$ are time subscripts denoting the beginning and end of period $(t-1, t), S_{i}$ is the share of sector $i$ in total employment. The first component of equation (13) is the within-sector effect, which captures the impact of productivity growth within individual sectors on overall productivity growth. The second component is the static reallocation or between effect, which reflects the impact of changes in the sectoral composition of employment; i.e., the impact of employment shift from less productive to more productive sectors. The third component, is the dynamic reallocation or cross effect, which captures the joint effect of changes in employment shares and sectoral productivity; i.e., contribution arising from whether expanding sectors have above-average or below-average productivity growth. 
In all regions, within-sector productivity improvements were by far the most important driver of aggregate productivity growth during 1995-2005, and their relative importance increased during the later part of the period (Table 10). Productivity improvements were in part associated with labor shedding, but were mostly attributable to higher efficiency arising from privatization and adoption of new technologies and managerial techniques. Entry of new firms, which tend to show higher productivity, were also a likely contributory factor.

The reallocation effects were small and their importance fell over time. The static reallocation or between effect was initially positive during 1995-2001 but turned negative in the succeeding years in all regions, with the exception of Trnava and Kosice. Significantly, the dynamic reallocation or cross effect also turned negative during 2002-05 period in three of the western regions (Trnava, Trencin, and Nitra) and one eastern region (Zilina). In general, the impact of the dynamic reallocation effect on aggregate productivity growth was bigger than that of the static reallocation effect.

The reallocation effects noted above reflect the combined impact of changes in the sectoral pattern of employment and the evolution of labor productivity in the different sectors. In all regions, there was a shift of labor away from agriculture and industry toward services. During 1995-2001, agriculture recorded the lowest productivity growth in all regions. For the country as a whole, productivity growth was higher in manufacturing than in services during this period, though productivity growth in services was greater than in manufacturing in three of the western regions except Bratislava. There was a marked recovery in agricultural productivity growth during 2002-05, while productivity growth in services became anemic and lagged the growth in other sectors by a considerable margin. Reflecting the dynamics of productivity growth, the relative position of agriculture in productivity level has turned around - the productivity levels in agriculture and manufacturing in recent years have risen to above that in services.

\section{Policy Challenges}

The preceding analysis has implications for the outlook for growth of per capita GDP and productivity. The constraints to sustaining high per capita GDP and productivity growth appear to be different in the eastern and western regions. The western regions are likely to remain attractive to investors, both foreign and domestic. Also, there is considerable potential for downstream integration with domestic supply chains for many FDI supported projects, especially in the automotive and electronics industries, thereby creating a multiplier effect on growth. However, the availability of skilled labor is likely to become a restraining factor. In contrast, there are concerns about the prospects for sustaining high growth in the eastern regions. In these regions, the restructuring process that boosted productivity growth is coming to an end. Productivity growth in recent years has come at the cost of lower labor utilization. Sustaining growth will require increasing the labor utilization ratio and improving the structural and policy determinants of productivity. 
The Slovak government implements active labor market programs (ALMP) aimed at supporting employment of disadvantaged groups in the labor market, such as the youth, older persons, and the long-term unemployed. But, the ALMP schemes have been limited in scope and have been less effective (measured in terms of raising exit rates from unemployment into employment following participation in a scheme) in the poorer eastern regions than in the richer western regions. ${ }^{4}$ New ALMP tools have been added from 2008 to raise the employability of job seekers and to increase the cost incentives for employers to employ disadvantaged groups. However, these schemes alone are not likely to provide a permanent and widespread cure for the low labor utilization in the eastern regions.

The eastern regions are at a disadvantage with regard to cost competitiveness. The level of unit labor costs over the years has been higher in the eastern regions than in the western regions. The gap had narrowed prior to 2002, as unit labor costs increased at a slower pace in the eastern regions. However, subsequently the gap has widened as the growth of unit labor costs in the eastern regions has picked up and exceeded the pace in the western regions (Table 11). Two possible explanations can be offered for the acceleration in growth of unit labor costs against a backdrop of very high unemployment. First, it may be symptomatic of an increasing degree of skill mismatch between labor supply and job vacancies. Second, it is possible that labor market institutions, especially steady increases in the minimum wage relative to the average wage, are hampering wage flexibility and greater regional wage differentiation. The minimum wage is used as a basis for the calculation of wage tariffs, a scale of minimum wages for the workers not covered by collective bargaining. The increases in the minimum wage were most likely pricing out low-skilled workers in the eastern regions. As Table 11 shows, during 1998-2006, the ratio of the minimum wage to average wage of unskilled workers increased by 1.9-7.2 percentage points in the western regions and by $8.1-18.5$ percentage points in the eastern regions. Also, the cost competitiveness of the eastern regions may deteriorate further on account of an amendment to the collective bargaining law in 2006. The amendment has made sectoral wage agreements binding for all enterprises in the sector, which is likely to be particularly painful to smaller enterprises. Greater productivity-based wage adjustments and enhanced wage flexibility could be achieved by expanding the scope of enterprise-level wage bargaining. Labor utilization of low-skilled workers would likely be boosted by moderation in minimum wage increases.

Attracting investment in the eastern regions would be key to improving productivity and sustaining growth. The impact would be felt through capital deepening as well as higher TFP associated with new technologies and better managerial techniques. With the aim of promoting greater domestic and foreign investment in less-developed regions with high unemployment and in the high-tech and $\mathrm{R} \& \mathrm{D}$ areas, from 2008 the Slovak government

\footnotetext{
${ }^{4}$ See IMF (2007).
} 
adopted revised guidelines for providing investment and employment incentives. ${ }^{5}$ Under this policy, projects with a certain minimum amount of investment in industrial production, technology centers, strategic service centers, and complex tourism centers will be eligible for assistance from the state budget. ${ }^{6}$ Maximum assistance levels will be 10 percent of eligible costs in the Bratislava region, 40 percent of eligible costs in the other western regions, and 50 percent of eligible costs in the central and eastern regions.

However, the success of the revised investment guidelines will depend on developing adequate infrastructure, especially a well-integrated transportation network. According to officials of SARIO, the Slovak Investment and Trade Development Agency, investors see the lack of adequate infrastructure in the eastern regions to be a major bottleneck. Notably, comprehensive incentive packages and tailored infrastructure programs have been vital to Slovakia's success in attracting investment from automotive groups. An important condition for investment in a new automobile plant in Zilina by Kia Motors was the extension of the motorway network. Overall, the progress on infrastructure projects in recent years has been disappointing. The drawdown of EU Cohesion Funds for infrastructure projects has been substantially below budgeted levels. ${ }^{7}$ In the periods ahead, EU funds for infrastructure will focus on the extension of motorway links between Zilina and the western regions. This will foster the emergence of a growth pole around Zilina. However, the medium-term prospects for major infrastructure improvements in the other eastern regions are not as encouraging. The east-west motorway corridor project is to be implemented through public-private partnership and is not expected to start until 2011.

Policies aimed at improving the accumulation of human capital will be important for alleviating labor market constraints to medium-term growth. Shortage of skilled labor is already a bottleneck in the Bratislava region and has resulted in increased wage pressures there. As discussed above, this factor may also be relevant in the eastern regions. Thus, effective utilization of EU funds to improve the quality of tertiary and vocational education will be crucial. The incentives being provided by the Slovak Government to investors to engage in in-house R\&D activities should also help.

\footnotetext{
${ }^{5}$ See National Council of the Slovak Republic (2007). Also, see the following weblink of SARIO, the Slovak Investment and Trade Development Agency: http://www.sario.sk/?rules-for-state-aid-provision. State aid can take a variety of forms such as subsidies for the acquisition of material and immaterial assets, income tax relief, contribution for creation of new jobs, and discounted price for land.

${ }^{6}$ The minimum amount of investment differs according to the type of investment and level of unemployment in the region where the project is located.

${ }^{7}$ See IMF (2007) for a cross-country comparison of drawdown of different categories of EU funds.
} 


\section{ConClusions}

An important finding of the paper is that, in a break from earlier trends, regional disparities in the levels of GDP per capita, labor productivity, and labor utilization have widened since 2000, coinciding with the time that Slovakia initiated negotiations on EU accession. The benefits of rapid economic growth appears to have only marginally touched three of the four eastern regions of Slovakia, where employment growth has been small and the unemployment rate remains sticky around 20 percent. However, notwithstanding $\sigma$ divergence in the levels, there has been conditional $\beta$-convergence in the growth rates of GDP per capita and labor productivity. There is heterogeneity in steady-states across regions, and regional growth is converging to these region-specific steady states.

Labor productivity was the main engine of growth of GDP in all regions, attributable primarily to improvements in TFP. The origins of the TFP efficiency gains were different between the eastern regions and western regions. TFP improvements in the western regions could be related to the technology and knowledge spillover aspects of FDI, while the gains in the eastern regions likely resulted from the restructuring process and labor shedding. While the investment ratio was not found to be a significant determinant of productivity growth in the econometric exercise, perhaps because of the small sample period and the process of creative destruction during the restructuring process, the growth accounting exercise shows that the contribution of capital deepening was significant.

Higher productivity growth in the western regions can be related to advantages in location, infrastructure stock and quality, human capital endowments, and attraction to foreign investors. These characteristics imply a favorable outlook for sustained growth in the western regions provided a shortage of skilled labor does not become a binding constraint. Unless the bottlenecks faced by the eastern regions with regard to these characteristics are addressed, regional disparities could exacerbate further. The eastern regions will require a boost from higher investment to spur an increase in the labor utilization rate and to sustain productivity

growth. This is unlikely to occur unless there is significant improvement in transportation infrastructure in the eastern regions. Improving cost competitiveness in the eastern regions is also a priority for stimulating employment growth. This could be fostered through labor market reforms that promote greater regional differentiation in wages and further decentralization of collective bargaining. Skill mismatches may have potentially harmful consequences for economic growth over the medium term in both the eastern and western regions. Thus, improvements in the accumulation of human capital will be crucial. Improvements in both physical and human capital call for a more speedy and effective utilization of EU funds. 


\section{REFERENCES}

Bernanke, B. and R. Gurkaynak, 2001, “Is Growth Exogenous? Taking Mankiw, Romer, and Weil Seriously,” in NBER Macroeconomics Annual 2001, Volume 16, pp 11-72.

Borys, M., E. Polgar, and A. Zlate, 2008, “Real Convergence and the Determinants of Growth in EU Candidate and Potential Candidate Countries: A Panel Data Approach,” European Central Bank Occasional Paper Series No.8, Frankfurt.

Bosworth, B. and S. Collins, 2003, “The Empirics of Growth: An Update,” Brookings Papers on Economic Activity, no. 2, pp. 113-206.

Bruncko, M., 2003, "Regional Convergence in the Slovak Republic and European Union Regional Funds,” in Funck, B. and Pizzati, L. (eds) European Integration, Regional Policy, and Growth, World Bank, Washington D.C., pp.183-94.

Havrylyshyn, O. and T. Wolf, 2001, "Growth in Transition Countries, 1990-1998: The Main Lessons," in O. Havrylyshyn and S. Nsouli (eds) A Decade of Transition: Achievements and Challenges, International Monetary Fund, Washington D.C.

International Monetary Fund, IMF, 2007, “Slovak Republic: 2007 Article IV ConsultationStaff Report,” IMF Country Report No. 07/226, Washington D.C., June.

Islam, N., 2003, “What Have We Learnt from the Convergence Debate,” Journal of Economic Surveys, vol. 17(3), pp. 309-62.

Mankiw, G., D. Romer, and D. Weil, 1992, “A Contribution to the Empirics of Economic Growth,” Quarterly Journal of Economics 107, pp. 407-37.

National Council of the Slovak Republic, 2007, “Government Draft Act of 20.10.2007 on investment aid and amendments to certain acts,” Bratislava. http://www.sario.sk/swift data/source/dokumenty/Investicie/pravidla/Act Investment Aid eng.pdf

Smarzynska-Javorcik, B., 2004, "Do Foreign Direct Investment Increase the Productivity of Domestic Firms? In Search of Spillovers through Backward Linkages,” American Economic Review, vol. 94(3), pp. 605-27.

Solow, R., 1956, “A Contribution to the Theory of Economic Growth,” Quarterly Journal of Economics 70, pp. 65-94.

Timmer, M. and A. Szirmai, 2000, "Productivity growth in Asian manufacturing: the structural bonus hypothesis examined," Structural Change and Economic Dynamics, vol. 11(4), pp. 371-92.

World Bank, 2008, Unleashing prosperity: Productivity Growth in Eastern Europe and the Former Soviet Union, Washington D.C. 
Table 1. Slovakia: Regional Differences in Real GDP per Capita and Household Disposable Income, 1995-2006

\begin{tabular}{|c|c|c|c|c|c|c|c|c|c|c|c|c|}
\hline & 1995 & 1996 & 1997 & 1998 & 1999 & 2000 & 2001 & 2002 & 2003 & 2004 & 2005 & 2006 \\
\hline & \multicolumn{12}{|c|}{ (Growth of GDP per capita in constant prices by regions, in percent) } \\
\hline Bratislava & & 5.2 & 7.8 & 4.5 & -1.0 & 3.1 & 5.4 & 7.4 & 4.2 & 5.6 & 14.6 & 4.2 \\
\hline Trnava & & 7.4 & 3.7 & 2.0 & 1.1 & -0.5 & 0.8 & 2.5 & 9.2 & 6.2 & 9.2 & 22.0 \\
\hline Trencin & & 8.4 & 3.4 & 4.3 & 1.1 & 1.8 & 3.4 & 1.9 & 5.4 & 5.8 & 1.4 & 14.8 \\
\hline Nitra & & 7.9 & 4.0 & 4.3 & 3.4 & 0.0 & 1.3 & 4.5 & 7.4 & 7.1 & 7.0 & 4.5 \\
\hline Zilina & & 8.6 & 5.8 & 4.5 & -0.8 & 1.4 & 4.8 & 3.5 & 2.5 & 6.3 & 8.3 & 6.6 \\
\hline Banska Bystrica & & 7.6 & 5.6 & 5.0 & -0.9 & 1.3 & 5.1 & 7.5 & 4.1 & 0.8 & -7.3 & 11.6 \\
\hline Presov & & 6.9 & 4.2 & 2.3 & -1.7 & 0.8 & 4.0 & 6.3 & 2.6 & 3.7 & 4.6 & 0.7 \\
\hline Kosice & & 9.6 & 5.6 & 6.6 & -0.3 & 0.2 & 7.1 & 2.0 & 3.1 & 4.3 & 1.8 & 8.3 \\
\hline Slovakia & & 7.4 & 5.3 & 4.2 & -0.1 & 1.3 & 3.8 & 4.8 & 4.7 & 5.1 & 6.5 & 8.4 \\
\hline Western regions & & 6.7 & 5.4 & 3.9 & 0.6 & 1.6 & 2.9 & 5.0 & 6.0 & 6.1 & 9.8 & 9.4 \\
\hline \multirow[t]{2}{*}{ Eastern regions } & & 8.3 & 5.3 & 4.7 & -0.9 & 0.9 & 5.4 & 4.6 & 3.1 & 3.8 & 1.8 & 6.9 \\
\hline & \multicolumn{12}{|c|}{ (Regional GDP per capita, in percent of Slovak average) } \\
\hline Bratislava & 214 & 210 & 215 & 215 & 213 & 217 & 220 & 226 & 225 & 226 & 243 & 234 \\
\hline Trnava & 110 & 110 & 108 & 106 & 107 & 105 & 102 & 100 & 104 & 105 & 108 & 122 \\
\hline Trencin & 94 & 94 & 93 & 93 & 94 & 94 & 94 & 91 & 92 & 93 & 88 & 93 \\
\hline Nitra & 86 & 86 & 85 & 85 & 88 & 87 & 85 & 85 & 87 & 88 & 89 & 86 \\
\hline Zilina & 81 & 82 & 82 & 82 & 82 & 82 & 83 & 82 & 80 & 81 & 82 & 81 \\
\hline Banska Bystrica & 83 & 83 & 83 & 84 & 83 & 83 & 84 & 86 & 86 & 82 & 72 & 74 \\
\hline Presov & 64 & 64 & 63 & 62 & 61 & 61 & 61 & 62 & 61 & 60 & 59 & 55 \\
\hline Kosice & 87 & 89 & 89 & 91 & 91 & 90 & 93 & 90 & 89 & 88 & 84 & 84 \\
\hline Slovakia & 100 & 100 & 100 & 100 & 100 & 100 & 100 & 100 & 100 & 100 & 100 & 100 \\
\hline Western regions & 125 & 124 & 124 & 124 & 125 & 125 & 124 & 124 & 126 & 127 & 131 & 132 \\
\hline Eastern regions & 79 & 79 & 79 & 80 & 79 & 79 & 80 & 80 & 78 & 77 & 74 & 73 \\
\hline \multirow{2}{*}{\multicolumn{13}{|c|}{$\begin{array}{l}\text { Memorandum item: } \\
\text { Coefficient of variation } 1 /\end{array}$}} \\
\hline & & & & & & & & & & & & \\
\hline All regions & 0.440 & 0.424 & 0.441 & 0.442 & 0.436 & 0.450 & 0.460 & 0.478 & 0.476 & 0.481 & 0.547 & 0.525 \\
\hline \multirow[t]{2}{*}{ Excluding Bratislava } & 0.149 & 0.150 & 0.146 & 0.144 & 0.152 & 0.149 & 0.142 & 0.131 & 0.146 & 0.153 & 0.173 & 0.227 \\
\hline & \multicolumn{12}{|c|}{ (Regional per capita household disposable income, in percent of Slovak average) } \\
\hline Bratislava & 133 & 134 & 138 & 142 & 146 & 147 & 148 & 149 & 150 & 155 & 163 & 156 \\
\hline Trnava & 103 & 103 & 102 & 100 & 99 & 99 & 100 & 100 & 102 & 104 & 99 & 103 \\
\hline Trencin & 98 & 98 & 98 & 96 & 93 & 94 & 95 & 96 & 95 & 98 & 95 & 97 \\
\hline Nitra & 96 & 96 & 94 & 95 & 95 & 95 & 97 & 100 & 98 & 98 & 96 & 97 \\
\hline Zilina & 90 & 89 & 88 & 90 & 93 & 93 & 94 & 93 & 94 & 92 & 93 & 92 \\
\hline Banska Bystrica & 98 & 97 & 99 & 97 & 96 & 96 & 95 & 94 & 94 & 93 & 94 & 94 \\
\hline Presov & 86 & 87 & 87 & 88 & 88 & 87 & 85 & 84 & 84 & 83 & 80 & 79 \\
\hline Kosice & 101 & 101 & 100 & 98 & 97 & 95 & 95 & 92 & 92 & 90 & 91 & 92 \\
\hline Slovakia & 100 & 100 & 100 & 100 & 100 & 100 & 100 & 100 & 100 & 100 & 100 & 100 \\
\hline Western regions & 107 & 107 & 107 & 108 & 108 & 109 & 109 & 111 & 111 & 113 & 113 & 113 \\
\hline Eastern regions & 94 & 94 & 94 & 93 & 93 & 93 & 92 & 91 & 91 & 89 & 89 & 89 \\
\hline \multirow{2}{*}{\multicolumn{13}{|c|}{$\begin{array}{l}\text { Memorandum item: } \\
\text { Coefficient of variation } 1 /\end{array}$}} \\
\hline & & & & & & & & & & & & \\
\hline All regions & 0.134 & 0.136 & 0.151 & 0.160 & 0.172 & 0.177 & 0.182 & 0.189 & 0.189 & 0.210 & 0.241 & 0.216 \\
\hline Excluding Bratislava & 0.058 & 0.055 & 0.056 & 0.040 & 0.035 & 0.036 & 0.047 & 0.055 & 0.054 & 0.067 & 0.061 & 0.072 \\
\hline
\end{tabular}

Sources: Statistical Office of the Slovak Republic; and authors' calculations.

1 / Coefficient of variation is defined as standard deviation of the regional distribution divided by Slovak average. 
Table 2. Slovakia: Regional Differences in Labor Productivity, 1995-2006

\begin{tabular}{|c|c|c|c|c|c|c|c|c|c|c|c|c|}
\hline & 1995 & 1996 & 1997 & 1998 & 1999 & 2000 & 2001 & 2002 & 2003 & 2004 & 2005 & 2006 \\
\hline & \multicolumn{12}{|c|}{ (Growth of labor productivity in constant prices by regions, in percent) } \\
\hline Bratislava & & 1.9 & 9.9 & 6.3 & -2.9 & 1.2 & -2.1 & 9.5 & 4.4 & 3.6 & 8.1 & 5.5 \\
\hline Trnava & & 11.4 & 19.4 & -3.9 & 2.7 & 0.7 & -0.3 & -0.5 & 8.4 & 3.8 & 9.1 & 18.4 \\
\hline Trencin & & -5.3 & -6.3 & 5.2 & 8.3 & 2.7 & 2.1 & -0.1 & 4.0 & 4.0 & 0.8 & 12.0 \\
\hline Nitra & & 10.2 & 5.6 & 5.4 & 5.1 & 4.1 & 2.3 & 3.7 & 7.0 & 5.6 & 5.9 & 1.1 \\
\hline Zilina & & 5.8 & 3.7 & 4.8 & 6.2 & 1.5 & 7.0 & -0.2 & -1.2 & 12.6 & 3.2 & 6.1 \\
\hline Banska Bystrica & & 4.5 & 5.5 & 11.1 & -0.4 & 3.7 & 6.1 & 8.3 & 6.7 & 4.6 & -8.2 & 8.7 \\
\hline Presov & & 2.9 & 10.2 & -2.2 & 2.3 & 5.6 & 6.2 & 6.9 & -1.2 & 3.2 & 11.7 & -5.3 \\
\hline Kosice & & 13.6 & 5.6 & 10.2 & 2.9 & 6.9 & 4.7 & 5.6 & 1.4 & 5.9 & 1.7 & 5.2 \\
\hline Slovakia & & 5.4 & 6.6 & 4.9 & 2.6 & 3.4 & 2.8 & 4.7 & 3.6 & 5.4 & 5.1 & 6.1 \\
\hline Western regions & & 4.1 & 7.1 & 3.9 & 2.3 & 2.3 & 0.2 & 4.4 & 5.5 & 4.1 & 7.1 & 7.8 \\
\hline \multirow[t]{2}{*}{ Eastern regions } & & 6.9 & 6.2 & 6.1 & 2.8 & 4.4 & 6.1 & 4.9 & 1.3 & 6.5 & 1.9 & 3.8 \\
\hline & \multicolumn{12}{|c|}{ (Regional productivity in percent of Slovak average) } \\
\hline Bratislava & 147 & 142 & 147 & 149 & 141 & 138 & 131 & 137 & 138 & 136 & 140 & 139 \\
\hline Trnava & 104 & 110 & 123 & 113 & 113 & 110 & 107 & 101 & 106 & 104 & 108 & 121 \\
\hline Trencin & 113 & 102 & 89 & 90 & 95 & 94 & 93 & 89 & 89 & 88 & 85 & 89 \\
\hline Nitra & 90 & 94 & 93 & 93 & 95 & 96 & 96 & 95 & 98 & 98 & 99 & 94 \\
\hline Zilina & 87 & 87 & 85 & 85 & 87 & 86 & 89 & 85 & 81 & 87 & 85 & 85 \\
\hline Banska Bystrica & 85 & 84 & 83 & 88 & 85 & 86 & 88 & 91 & 94 & 93 & 82 & 84 \\
\hline Presov & 77 & 75 & 78 & 73 & 72 & 74 & 76 & 78 & 74 & 73 & 78 & 69 \\
\hline Kosice & 86 & 92 & 91 & 96 & 96 & 100 & 101 & 102 & 100 & 101 & 97 & 96 \\
\hline Slovakia & 100 & 100 & 100 & 100 & 100 & 100 & 100 & 100 & 100 & 100 & 100 & 100 \\
\hline Western regions & 117 & 115 & 116 & 115 & 114 & 113 & 110 & 110 & 112 & 110 & 113 & 114 \\
\hline Eastern regions & 84 & 85 & 85 & 85 & 86 & 86 & 89 & 89 & 87 & 88 & 86 & 84 \\
\hline \multicolumn{13}{|l|}{$\begin{array}{l}\text { Memorandum item: } \\
\text { Coefficient of variation } 1 /\end{array}$} \\
\hline All regions & 0.214 & 0.194 & 0.223 & 0.219 & 0.194 & 0.182 & 0.153 & 0.170 & 0.182 & 0.173 & 0.192 & 0.211 \\
\hline Excluding Bratislava & 0.128 & 0.116 & 0.151 & 0.125 & 0.125 & 0.117 & 0.097 & 0.087 & 0.112 & 0.107 & 0.114 & 0.162 \\
\hline
\end{tabular}

Sources: Statistical Office of the Slovak Republic; and authors' calculations.

1 / Coefficient of variation is defined as standard deviation of the regional distribution divided by Slovak average. 
Table 3. Slovakia: Regional Differences in Labor Utilization and Unemployment, 1995-2006

\begin{tabular}{|c|c|c|c|c|c|c|c|c|c|c|c|c|}
\hline & 1995 & 1996 & 1997 & 1998 & 1999 & 2000 & 2001 & 2002 & 2003 & 2004 & 2005 & 2006 \\
\hline & \multicolumn{12}{|c|}{ (Labor utilzation rate by regions, in percent) $1 /$} \\
\hline Bratislava & 57.2 & 59.0 & 57.9 & 56.9 & 58.0 & 59.1 & 63.6 & 62.5 & 62.3 & 63.5 & 67.4 & 66.6 \\
\hline Trnava & 41.5 & 40.0 & 34.7 & 36.9 & 36.3 & 35.9 & 36.3 & 37.4 & 37.7 & 38.5 & 38.5 & 39.7 \\
\hline Trencin & 32.5 & 37.2 & 41.0 & 40.7 & 38.0 & 37.7 & 38.1 & 38.9 & 39.4 & 40.1 & 40.4 & 41.4 \\
\hline Nitra & 37.5 & 36.7 & 36.2 & 35.8 & 35.3 & 33.9 & 33.6 & 33.8 & 34.0 & 34.4 & 34.8 & 36.0 \\
\hline Zilina & 36.8 & 37.7 & 38.4 & 38.3 & 35.8 & 35.7 & 35.0 & 36.3 & 37.7 & 35.6 & 37.3 & 37.5 \\
\hline Banska Bystrica & 38.5 & 39.6 & 39.6 & 37.5 & 37.3 & 36.4 & 36.1 & 35.8 & 34.9 & 33.6 & 34.0 & 34.9 \\
\hline Presov & 32.8 & 34.0 & 32.2 & 33.6 & 32.3 & 30.8 & 30.2 & 30.0 & 31.2 & 31.3 & 29.3 & 31.2 \\
\hline Kosice & 39.9 & 38.5 & 38.5 & 37.3 & 36.1 & 33.8 & 34.6 & 33.4 & 34.0 & 33.5 & 33.5 & 34.5 \\
\hline Slovakia & 39.3 & 40.0 & 39.5 & 39.3 & 38.3 & 37.5 & 37.9 & 37.9 & 38.3 & 38.2 & 38.7 & 39.5 \\
\hline Western regions & 42.0 & 43.1 & 42.4 & 42.5 & 41.8 & 41.5 & 42.6 & 42.8 & 43.0 & 43.8 & 44.9 & 45.6 \\
\hline Eastern regions & 36.9 & 37.4 & 37.1 & 36.6 & 35.3 & 34.1 & 33.8 & 33.7 & 34.3 & 33.4 & 33.4 & 34.4 \\
\hline \multicolumn{13}{|l|}{ Memorandum item: } \\
\hline All regions & 0.185 & 0.182 & 0.185 & 0.173 & 0.196 & 0.220 & 0.258 & 0.249 & 0.240 & 0.255 & 0.286 & 0.263 \\
\hline \multirow[t]{2}{*}{ Excluding Bratislava } & 0.085 & 0.050 & 0.076 & 0.055 & 0.049 & 0.062 & 0.071 & 0.084 & 0.080 & 0.096 & 0.109 & 0.102 \\
\hline & \multicolumn{12}{|c|}{ (Unemployment rate by regions, in percent) $3 /$} \\
\hline Bratislava & & & & 6.0 & 7.4 & 7.2 & 8.3 & 8.6 & 6.9 & 8.2 & 5.2 & 4.3 \\
\hline Trnava & & & & 11.8 & 12.3 & 16.4 & 18.0 & 16.1 & 13.2 & 12.5 & 10.4 & 8.8 \\
\hline Trencin & & & & 7.7 & 11.4 & 15 & 13.4 & 11.3 & 9.2 & 8.6 & 8.1 & 7.1 \\
\hline Nitra & & & & 12.1 & 17.8 & 20.8 & 23.1 & 23.8 & 23.4 & 20.3 & 17.8 & 13.2 \\
\hline Zilina & & & & 10.5 & 15.9 & 18.5 & 18.9 & 17.3 & 17.2 & 17.5 & 15.2 & 11.8 \\
\hline Banska Bystrica & & & & 15.6 & 21.1 & 21.9 & 22.4 & 25.2 & 23.8 & 26.6 & 23.8 & 21.1 \\
\hline Presov & & & & 16.4 & 19.1 & 22.1 & 22.7 & 20.1 & 20.4 & 22.9 & 21.5 & 18.1 \\
\hline Kosice & & & & 18.7 & 23.1 & 25.6 & 24.8 & 24.1 & 23.0 & 25.2 & 24.7 & 20.3 \\
\hline Slovakia & & & & 12.5 & 16.2 & 18.6 & 19.2 & 18.5 & 17.4 & 18.1 & 16.2 & 13.3 \\
\hline
\end{tabular}

Sources: Statistical Office of the Slovak Republic; and authors' calculations.

$1 /$ Labor utilization rate measured as total employment (ESA definition) divided by total population.

2/ Coefficient of variation is defined as standard deviation of the regional distribution divided by Slovak average.

3/ Unemployment rate as per labor force survey. 
Table 4. Dispersion of Regional GDP per Capita in the European Union, 1996-2005 1/

\begin{tabular}{|c|c|c|c|c|c|c|}
\hline & \multirow[b]{2}{*}{1996} & \multirow[b]{2}{*}{1999} & \multirow[b]{2}{*}{2002} & \multirow[b]{2}{*}{2005} & \multicolumn{2}{|c|}{$\begin{array}{c}\text { Change, } \\
\text { in Percentage Points }\end{array}$} \\
\hline & & & & & 1996-2005 & 1999-2005 \\
\hline \multicolumn{7}{|l|}{ New Member States } \\
\hline Bulgaria & 24.4 & 26.4 & 30.3 & 32.5 & 8.1 & 6.1 \\
\hline Czech Republic & 15.3 & 20.4 & 23.3 & 23.3 & 8.0 & 2.9 \\
\hline Estonia & 31.6 & 36.1 & 40.2 & 41.2 & 9.6 & 5.1 \\
\hline Hungary & 33.4 & 37.6 & 38.8 & 40.0 & 6.6 & 2.4 \\
\hline Latvia & 31.7 & 46.1 & 51.9 & 51.3 & 19.6 & 5.2 \\
\hline Lithuania & 11.3 & 17.3 & 23.0 & 23.5 & 12.2 & 6.2 \\
\hline Slovakia & 27.2 & 27.3 & 28.1 & 33.8 & 6.6 & 6.5 \\
\hline Slovenia & 19.1 & 20.0 & 20.9 & 22.4 & 3.3 & 2.4 \\
\hline Romania & 13.8 & 24.6 & 30.8 & 31.9 & 18.1 & 7.3 \\
\hline \multicolumn{7}{|l|}{ Old Member States } \\
\hline Austria & 26.8 & 26.1 & 25.9 & 25.1 & -1.7 & -1.0 \\
\hline Belgium & 27.9 & 28.1 & 27.5 & 27.5 & -0.4 & -0.6 \\
\hline Finland & 17.3 & 21.6 & 20.8 & 19.8 & 2.5 & -1.8 \\
\hline France & 22.5 & 23.3 & 23.5 & 22.7 & 0.2 & -0.6 \\
\hline Germany & 27.3 & 28.1 & 28.1 & 28.3 & 1.0 & 0.2 \\
\hline Greece & & & 25.4 & 29.1 & 3.7 & 3.721 \\
\hline Ireland & 18.5 & 22.1 & 25.8 & 25.9 & 7.4 & 3.8 \\
\hline Italy & 24.8 & 24.2 & 24.8 & 24.2 & -0.6 & 0.0 \\
\hline Netherlands & 15.9 & 16.3 & 16.2 & 17.2 & 1.3 & 0.9 \\
\hline Portugal & 26.2 & 26.2 & 26.9 & 28.1 & 1.9 & 1.9 \\
\hline Spain & 19.5 & 20.6 & 19.6 & 18.0 & -1.5 & -2.6 \\
\hline Sweden & 11.9 & 15.3 & 14.6 & 15.5 & 3.6 & 0.2 \\
\hline United Kingdom & 19.6 & 25.5 & 27.2 & 26.5 & 6.9 & 1.0 \\
\hline \multicolumn{7}{|l|}{ Memorandum item: } \\
\hline Poland 3/ & 15.3 & 17.5 & 17.9 & 19.4 & 1.9 & 4.1 \\
\hline
\end{tabular}

Source: Eurostat.

1/ At the NUTS III level. The dispersion of GDP per capita is measured by the sum of the absolute differences between regional and national GDP per capita, weighted by the share of population and expressed in percent of national GDP per capita.

2/ Change during 2002-05.

3/ At the NUTS II level. Data for Poland are not available at the NUTS III level. 
Table 5. Regression Analysis of $\beta$ (Beta)-Convergence of GDP per Capita Growth (Dependent variable: $\Delta \ln ($ GDP per capita))

\begin{tabular}{|c|c|c|c|c|}
\hline & \multicolumn{2}{|c|}{ Unconditional Convergence } & \multicolumn{2}{|c|}{ Conditional Convergence } \\
\hline & $\begin{array}{c}\text { Coefficient } \\
\text { (standard error) }^{a} \\
1996-2006\end{array}$ & $\begin{array}{c}\text { Coefficient } \\
\text { (standard error) }^{a} \\
2000-06 \\
\end{array}$ & $\begin{array}{c}\text { Coefficient } \\
\text { (standard error) }^{a} \\
1996-2006\end{array}$ & $\begin{array}{l}\text { Coefficient } \\
\text { (standard error) }^{a} \\
2000-06\end{array}$ \\
\hline & $(1)$ & $(2)$ & (3) & $(4)$ \\
\hline Constant & $\begin{array}{c}-0.16903 \\
(0.07491)^{\star \star}\end{array}$ & $\begin{array}{c}-0.33817 \\
(0.13263)^{\star \star}\end{array}$ & $\begin{array}{c}2.34792 \\
(0.94750)^{\star \star}\end{array}$ & $\begin{array}{c}2.76547 \\
(1.81416)\end{array}$ \\
\hline In (GDP per capita ${ }_{t-1}$ ) & $\begin{array}{c}0.01769 \\
(0.00631)^{\star \star \star}\end{array}$ & $\begin{array}{c}0.03169 \\
(0.01116)^{\star \star \star}\end{array}$ & $\begin{array}{c}-0.19122 \\
(0.07864)^{\star \star}\end{array}$ & $\begin{array}{l}-0.22455 \\
(0.14978)\end{array}$ \\
\hline Region fixed effects & No & No & Yes & Yes \\
\hline Time fixed effects & No & No & Yes & Yes \\
\hline Adjusted R-squared & 0.01958 & 0.06513 & 0.30270 & 0.15323 \\
\hline $\mathrm{F}$ & 2.73753 & $4.83177^{\star *}$ & $3.0982^{\star \star *}$ & $1.71092^{*}$ \\
\hline $\mathrm{N}$ & 88 & 56 & 88 & 56 \\
\hline
\end{tabular}

${ }^{a}$ Standard errors corrected for heteroscedasticity and autocorrelation.

*** Significant at the 1 percent level.

** Significant at the 5 percent level.

* Significant at the 10 percent level. 
Table 6. Regression Analysis of $\beta$ (Beta)-Convergence of Labor Productivity Growth (Dependent variable: $\Delta \ln ($ labor productivity))

\begin{tabular}{|c|c|c|c|c|c|c|c|}
\hline & \multicolumn{2}{|c|}{ Unconditional Convergence } & \multicolumn{2}{|c|}{ Conditional Convergence } & \multicolumn{2}{|c|}{ Solow Model } & \multirow{2}{*}{$\begin{array}{c}\text { Mankiw-Romer-Weil Model } \\
\text { Coefficient } \\
\text { (standard error) }^{a} \\
1996-2006 \\
\end{array}$} \\
\hline & $\begin{array}{c}\text { Coefficient } \\
\text { (standard error) }^{a} \\
1996-2006\end{array}$ & $\begin{array}{c}\text { Coefficient } \\
\text { (standard error) }^{a} \\
2000-06\end{array}$ & $\begin{array}{c}\text { Coefficient } \\
\text { (standard error) }^{a} \\
1996-2006\end{array}$ & $\begin{array}{c}\text { Coefficient } \\
\text { (standard error) }^{a} \\
2000-06\end{array}$ & $\begin{array}{c}\text { Coefficient } \\
\text { (standard error) }^{a} \\
1996-2006\end{array}$ & $\begin{array}{c}\text { Coefficient } \\
\text { (standard error) }^{a} \\
2000-06 \\
\end{array}$ & \\
\hline & (1) & (2) & (3) & (4) & (5) & (6) & (7) \\
\hline Constant & $\begin{array}{c}0.02733 \\
(0.01051)^{\star \star}\end{array}$ & $\begin{array}{c}0.04833 \\
(0.01716)^{\star \star \star}\end{array}$ & $\begin{array}{c}-0.44243 \\
(0.04743)^{\star \star \star}\end{array}$ & $\begin{array}{c}-0.50849 \\
(0.11817)^{\star \star \star}\end{array}$ & $\begin{array}{l}-0.18065 \\
(0.23370)\end{array}$ & $\begin{array}{l}-0.28573 \\
(0.29477)\end{array}$ & $\begin{array}{l}-0.49132 \\
(0.23620)^{\star \star}\end{array}$ \\
\hline In (labor productivity ${ }_{t-1}$ ) & $\begin{array}{l}-0.02016 \\
(0.01412)\end{array}$ & $\begin{array}{c}0.00938 \\
(0.02196)\end{array}$ & $\begin{array}{c}-0.60134 \\
(0.05868)^{\star \star \star}\end{array}$ & $\begin{array}{c}-0.75359 \\
(0.16193)^{\star \star \star}\end{array}$ & $\begin{array}{l}-0.31912 \\
(0.13631)^{\star \star}\end{array}$ & $\begin{array}{c}-0.55877 \\
(0.15476)^{\star \star \star}\end{array}$ & $\begin{array}{c}-0.61611 \\
(0.12025)^{\star \star \star}\end{array}$ \\
\hline In(investment ratio) ${ }^{b}$ & & & & & $\begin{array}{l}-0.00566 \\
(0.10234)\end{array}$ & $\begin{array}{c}0.02861 \\
(0.14349)\end{array}$ & $\begin{array}{c}0.07607 \\
(0.13154)\end{array}$ \\
\hline In(employment growth) ${ }^{c}$ & & & & & $\begin{array}{l}-0.82191 \\
(0.12575)^{\star \star \star}\end{array}$ & $\begin{array}{c}-0.80968 \\
(0.26436)^{\star \star \star}\end{array}$ & $\begin{array}{l}-0.70806 \\
(0.29428)^{\star \star}\end{array}$ \\
\hline $\begin{array}{l}\text { In(share of higher educated } \\
\text { persons in workforce })^{d}\end{array}$ & & & & & & & $\begin{array}{c}-0.39352 \\
(0.09763)^{\star \star \star}\end{array}$ \\
\hline Region fixed effects & No & No & Yes & Yes & Yes & Yes & Yes \\
\hline Time fixed effects & No & No & Yes & Yes & Yes & Yes & Yes \\
\hline $\begin{array}{l}\text { Adjusted R-squared } \\
\text { F }\end{array}$ & $\begin{array}{l}-0.00232 \\
0.79880\end{array}$ & $\begin{array}{l}-0.01675 \\
0.09416\end{array}$ & $\begin{array}{c}0.32151 \\
3.29038^{\star \star \star}\end{array}$ & $\begin{array}{l}0.14762 \\
1.68039^{\star}\end{array}$ & $\begin{array}{c}0.60879 \\
7.76947^{\star \star \star}\end{array}$ & $\begin{array}{c}0.33405 \\
2.72432^{\star \star \star}\end{array}$ & $\begin{array}{c}0.40537 \\
3.20556^{\star \star \star}\end{array}$ \\
\hline $\begin{array}{l}\text { F-statistic to test significance of } \\
\text { Region fixed effects } \\
\text { Time fixed effects } \\
\text { Region and time fixed effects }\end{array}$ & & & $\begin{array}{l}6.2522^{\star \star \star} \\
4.1124^{\star \star \star} \\
3.2941^{\star \star \star}\end{array}$ & $\begin{array}{c}2.8127^{\star \star} \\
3.7511^{\star \star \star} \\
1.8010^{\star}\end{array}$ & $\begin{array}{c}2.0621^{\star} \\
10.4932^{\star \star \star} \\
6.6085^{\star \star \star}\end{array}$ & $\begin{array}{c}2.3913^{\star \star} \\
4.0741^{\star \star \star} \\
2.1229^{\star \star}\end{array}$ & $\begin{array}{l}3.3796^{\star \star \star} \\
5.3892^{\star \star \star} \\
2.8052^{\star \star \star}\end{array}$ \\
\hline $\mathrm{N}$ & 88 & 56 & 88 & 56 & 88 & 56 & 56 \\
\hline
\end{tabular}

${ }^{a}$ Standard errors corrected for heteroscedasticity and autocorrelation.

Investment ratio measured as nominal gross fixed capital formation divided by nominal GDP.

Employment growth measured as ((employment $t_{t} /$ employment $\left.\left.t_{t-1}\right)+0.05\right)$, where 0.05 represents the sum of rate of technological progess and depreciation of capital.

${ }^{a}$ Higher education is defined as upper secondary and university education.

*** Significant at the 1 percent level.

** Significant at the 5 percent level.

* Significant at the 10 percent level. 
Table 7. Slovakia: Sources of Growth of GDP and Labor Producivity by Regions, 1996-2006

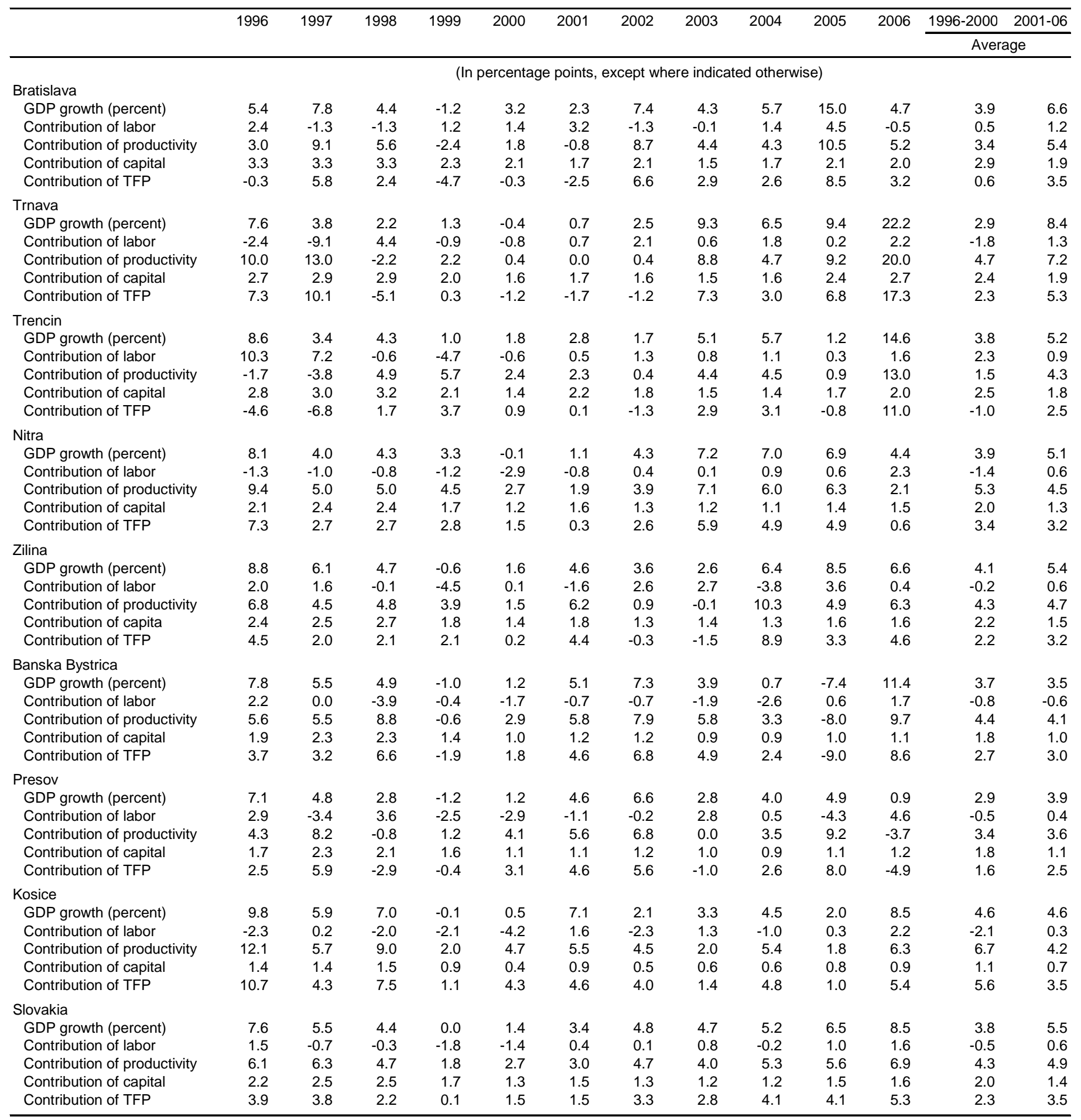

Source: Authors' calculations based on data from the Statistical Office of the Slovak Republic. 
Table 8. Motorways and Junctions Density by Regions (Kilometers per thousand square kilometers)

\begin{tabular}{lrr}
\hline & 2001 & 2005 \\
\hline Bratislava & 46.53 & 52.14 \\
Trnava & 16.26 & 16.26 \\
Trencin & 14.14 & 17.08 \\
Nitra & 0 & 0 \\
Zilina & 6.73 & 6.84 \\
Banska Bystrica & 0 & 0 \\
Presov & 2.09 & 3.40 \\
Kosice & 0.79 & 0.79 \\
Slovakia & 6.05 & 6.81 \\
\hline
\end{tabular}

Sources: Statistical Office of the Slovak Republic; and authors' calculations. 
Table 9. Slovakia: Foreign Direct Investment in the Corporate Sector by Regions, 1999-2006

\begin{tabular}{lrrrrrrrr}
\hline & 1999 & 2000 & 2001 & 2002 & 2003 & 2004 & 2005 & 2006 \\
\hline \multicolumn{7}{r}{} & \multicolumn{7}{c}{ (Outstanding stock, in millions of U.S. dollars) } \\
Bratislava & $1,043.5$ & $1,770.8$ & $1,906.9$ & $4,119.6$ & $5,456.2$ & $7,178.6$ & $6,690.6$ & $9,835.5$ \\
Trnava & 202.0 & 204.1 & 206.8 & 337.5 & 533.5 & 840.1 & 776.4 & 995.0 \\
Trencin & 153.1 & 142.4 & 144.8 & 228.2 & 362.8 & 615.3 & 664.0 & 885.9 \\
Nitra & 86.2 & 95.0 & 136.3 & 215.0 & 323.6 & 456.2 & 431.6 & 681.7 \\
Zilina & 80.3 & 179.7 & 210.2 & 305.7 & 428.5 & 673.2 & 791.0 & $1,319.7$ \\
Banska Bystrica & 112.6 & 114.4 & 161.3 & 208.2 & 270.1 & 357.4 & 358.5 & 475.8 \\
Presov & 100.2 & 100.1 & 113.4 & 146.7 & 182.4 & 249.6 & 231.6 & 296.0 \\
Kosice & 187.3 & 810.5 & 770.1 & 819.1 & $1,036.0$ & $1,208.4$ & $1,129.6$ & $1,439.2$ \\
Slovakia, total & $1,965.2$ & $3,417.1$ & $3,649.8$ & $6,380.1$ & $8,593.1$ & $11,578.7$ & $11,073.3$ & $15,928.9$ \\
Western regions & $1,484.8$ & $2,212.3$ & $2,394.8$ & $4,900.3$ & $6,676.1$ & $9,090.2$ & $8,562.6$ & $12,398.1$ \\
Eastern regions & 480.4 & $1,204.7$ & $1,255.0$ & $1,479.7$ & $1,917.0$ & $2,488.6$ & $2,510.7$ & $3,530.7$ \\
& & $($ Region's share in total inflows into Slovakia, in percent) & & \\
Bratislava & 53 & 52 & 52 & 65 & 63 & 62 & 60 & 62 \\
Trnava & 10 & 6 & 6 & 5 & 6 & 7 & 7 & 6 \\
Trencin & 8 & 4 & 4 & 4 & 4 & 5 & 6 & 6 \\
Nitra & 4 & 3 & 4 & 3 & 4 & 4 & 4 & 4 \\
Zilina & 4 & 5 & 6 & 5 & 5 & 6 & 7 & 8 \\
Banska Bystrica & 6 & 3 & 4 & 3 & 3 & 3 & 3 & 3 \\
Presov & 5 & 3 & 3 & 2 & 2 & 2 & 2 & 2 \\
Kosice & 10 & 24 & 21 & 13 & 12 & 10 & 10 & 9 \\
Slovakia, total & 100 & 100 & 100 & 100 & 100 & 100 & 100 & 100 \\
Western regions & 76 & 65 & 66 & 77 & 78 & 79 & 77 & 78 \\
Eastern regions & 24 & 35 & 34 & 23 & 22 & 21 & 23 & 22 \\
\hline
\end{tabular}

Source: National Bank of Slovakia. 
Table 10. Sectoral Patterns of Labor Productivity Growth by Region

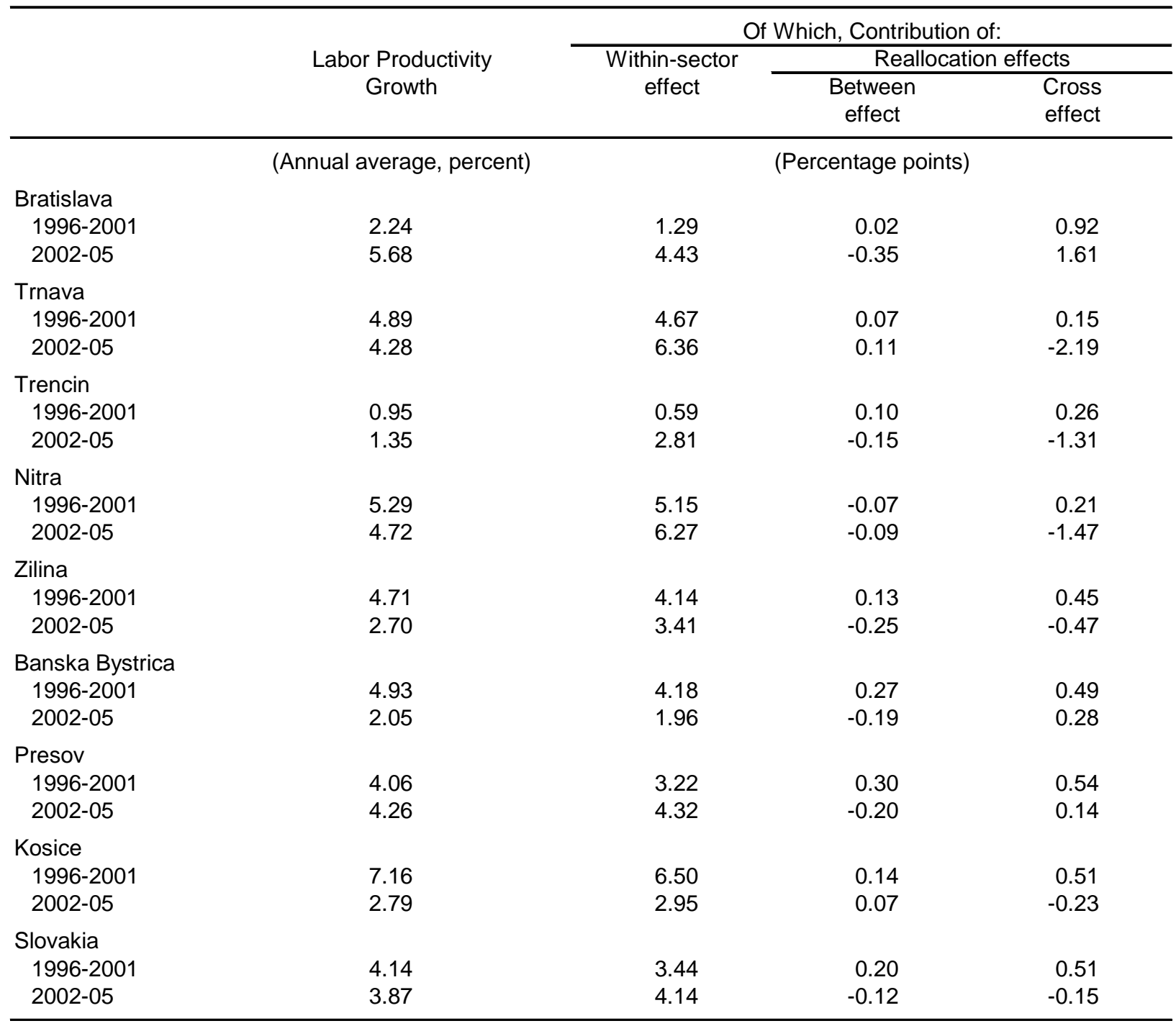

Source: Authors' calculations. 
Table 11. Unit Labor Costs and Minimum Wage by Regions, 1998-2006

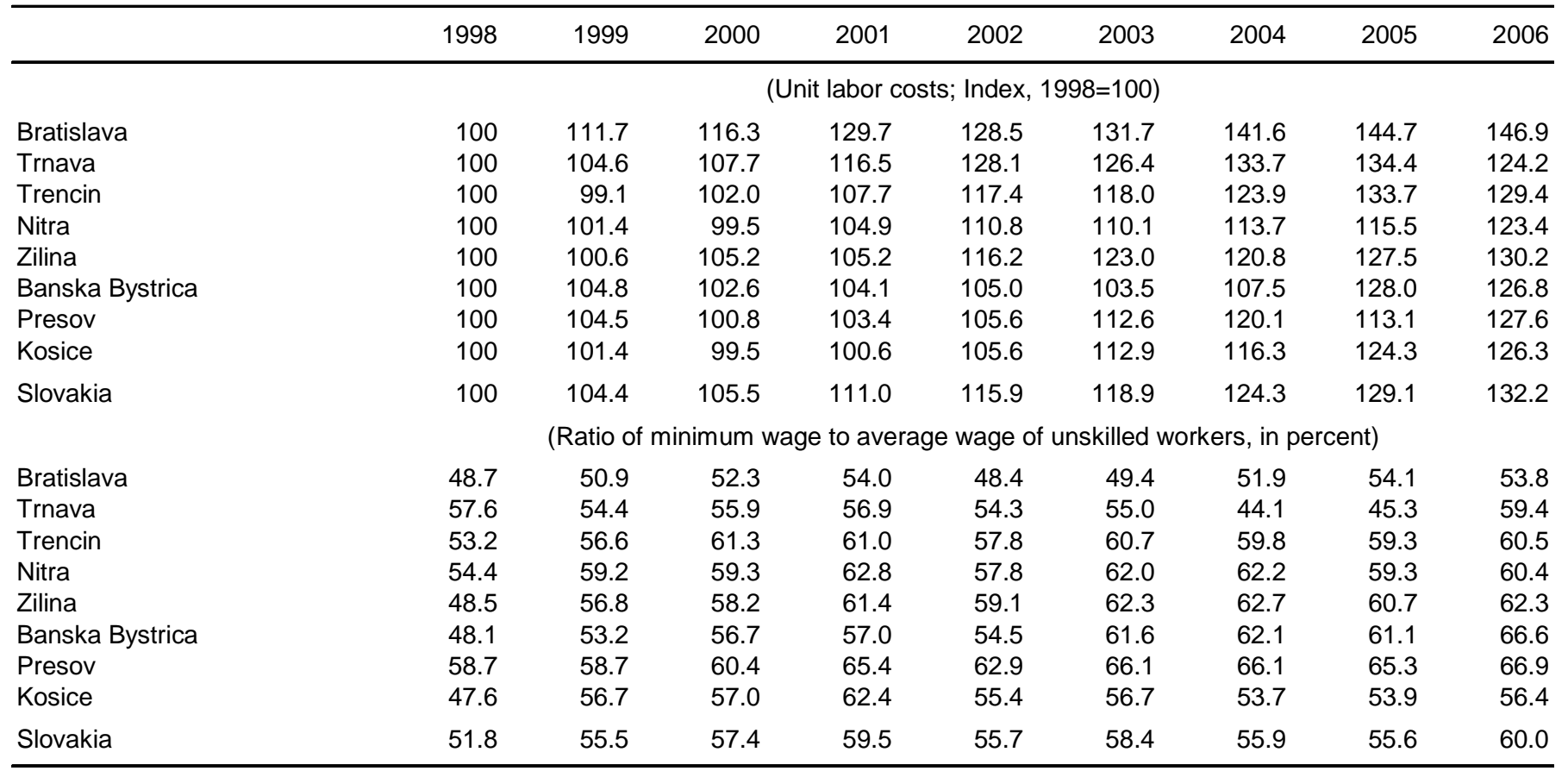

Source: Authors' calculations. 